\title{
KARAKTERISTIK KINERJA MODA ANGKUTAN UMUM KOTA PALOPO (STUDI KASUS PENUMPANG BUS EXECUTIVE, SUSPENSI UDARA, SCANIA - PO BINTANG PRIMA)
}

\author{
Rakhmawati Natsir ${ }^{1}$ \\ ${ }^{1}$ Dosen Program Studi Teknik Sipil Universitas Andi Djemma Palopo \\ 1'wathi07@gmail.com
}

\begin{abstract}
ABSTRAK
Transportasi mempunyai peranan penting dalam kehidupan manusia, karena tranportasi mempunyai pengaruh besar terhadap perorangan, masyarakat, pembangunan ekonomi, dan sosial suatu Negara.Sistem yang digunakan untuk mengangkut penumpang dan barang dengan menggunakan alat angkut tersebut dinamakan moda transportasi.Pemilihan moda dapat dikatakan sebagai tahap terpenting dalam perencanaan dan kebijakan transportasi. Hal ini menyangkut efisiensi pergerakan di daerah perkotaan, ruang yang harus disediakan kota untuk dijadikan prasarana transportasi, dan banyaknya pilihan moda transportasi yang biasa dipilih oleh penduduk. Salah satu moda transportasi darat yang digunakan adalah bus. Penelitian ini bertujuan untuk mengetahui faktor-faktor yang mempengaruhi keputusan konsumen dalam memilih jenis bus yang akan digunakan serta karakteristik penumpang. Instrumen penelitian ini menggunakan kuisioner yang dilakukan Uji Validitas dan Uji Reabilitas dengan menggunakan Software SPSS (Statistical Product and Service Solution). Dari hasil analisis diketahui faktor-faktor yang mempengaruhi konsumen adalah pelayanan awak bus, waktu pemberangkatan, Waktu Tempuh, harga, kenyamanan, keamanan dan keselamatan, penumpang. Adapun karakteristik penumpang adalah jenis kelamin, umur dan pekerjaan.
\end{abstract}

Kata kunci : Transporatsi, Moda Transportasi, Bus, dan SPSS.

\section{PENDAHULUAN}

Transportasi mempunyai peranan penting dalam kehidupan manusia, karena tranportasi mempunyai pengaruh besar terhadap perorangan, masyarakat, pembangunan ekonomi, dan sosial suatu Negara. Maka sudah seharusnya perkembangan dalam transportasi atau sistem pengangkutan khususnya angkutan darat harus dipikirkan sejak dini (Nova citra dewi, 2009). Secara umum angkutan ini sendiri dapat didefinisikan sebagai pemindahan orang dan/barang dari suatu tempat ke tempat lain dengan menggunakan kendaraan. Perangkutan diperlukan karena sumber kebutuhan manusia tidak terdapat disembarang tempat. Sistem yang digunakan untuk mengangkut penumpang dan barang dengan menggunakan alat angkut tersebut dinamakan moda transportasi.Pemilihan moda dapat dikatakan sebagai tahap terpenting dalam perencanaan dan kebijakan transportasi. Hal ini menyangkut efisiensi pergerakan di daerah perkotaan, ruang yang harus disediakan kota untuk dijadikan prasarana transportasi, dan banyaknya pilihan moda transportasi yang biasa dipilih oleh penduduk. Faktor ini adalah salah satu yang menjadi pertimbangan pelaku perjalanan dalam menentukan moda angkutan umum yang akan digunakan.Pertumbuhan wilayah di daerah perkotaan seperti Kota Makassar lebih cepat dibandingkan daerah lain di wilayah Sulawesi Selatan. Mengingat posisinya sebagai ibukota provinsi Sulawesi Selatan, hal ini menyebabkan kota Makassar banyak menawarkan berbagi macam sarana pendidikan dan lapangan pekerjaan. Semua ini merupakan daya tarik yang sangat kuat bagi masyarakat Sulawesi Selatan khususnya yang berasal dari kota Palopo.

Jarak kota Palopo ke Kota Makassar yang cukup jauh yakni $\pm 360 \mathrm{~km}$ menjadi salah satu pertimbangan dalam memilih bus sebagai alat transportasi menuju 
ke sana. Banyaknya jumlah PO Bus Trans Antarkota di Kota Palopo membuat masyarakat/konsumen memiliki banyak alternative pilihan Bus yang akan digunakan untuk menempuh perjalanan rute Palopo-Makassar. PO Bus Trans Antarkota dalam Provinsi yang ada di kota Palopo, antara lain Bintang Prima, Litha \& Co, Bintang Timur, Charisma, Gunung Rejeki, Alam Indah dan Pippos. Semua PO yang ada, belum tentu menyajikan pelayanan yang sama dari semua segi. Pemilihan PO sepenuhnya ditentukan oleh konsumen yang akan melakukan perjalanan.Dari sekian banyak pilihan PO, salah satu yang banyak diminati oleh masyarakat Kota Palopo adalah Bus Bintang Prima karena memiliki tiga jenis bus yang menjadi alternative pilihan penumpang yaitu jenis Executive, Suspensi Udara, dan Scania.Untuk menentukan pilihan Bus inilah pelaku perjalanan mempertimbangkan berbagai faktor, seperti harga tiket, kenyamanan, pelayanan awak bus, keamanan dan keselamatan penumpang, waktu pemberangkatan, dan waktu tempuh.

\section{BAHAN DAN METODE}

\section{Lokasi dan Rancangan Penelitian}

Penelitian dilakukan pada Perusahaan Organda (PO) Bintang Prima yang melayani rute Palopo-Makassar dan Makassar-Palopo. Metode penelitian ini terdiri atas dua bagian, yaitu Metode Penelitian Lapangan (Field Research Method) yang dilakukan dengan tujuan mengumpulkan data-data langsung dari lokasi, penyebaran kuisioner serta wawancara responden. Metode Penelitian Kepustakaan (Library Research Method) yaitu suatu pendekatan dengan membaca dan mengumpulkan data-data yang berhubungan dengan penelitian ini.

\section{Metode Pengumpulan Data}

Tahapan awal dari penelitian ini adalah mengumpulkan data sekunder dan data primer. Data sekunder yang digunakan diperoleh pada instansi/lembaga terkait, dokumen literature yang dianggap relevan. Data-data tersebut antara lain: daftar PO AKDP yang memiliki izin trayek rute Palopo-Makassar, perkembangan jumlah penumpang bus menuju makassar, jalur trayek, sistem tarif yang berlaku dan besaran tarif.Pengambilan data primer diperoleh dari hasil wawancara langsung (kuisioner) terhadap penumpang/responden terpilih di lokasi penelitian.

\section{Analisis Data}

Penelitian ini bersifat deskriptif yang bertujuan untuk mendeskripsikan atau memberikan gambaran tentang penumpang bus beserta faktor-faktor yang mempengaruhi konsumen dalam memilih bus yang akan digunakan. Instrumen penelitian (kuisioner) ini dilakukan Uji Validitas dan Uji Reabilitas dengan menggunakan Software SPSS (Statistical Product and Service Solution).

a) Uji Validitas

Validitas adalah suatu ukuran yang menunjukkan tingkat kevalidan atau kesahihan suatu instrumen. Suatu instrumen dianggap valid apabila mampu mengukur apa yang diinginkan. Dengan kata lain mampu memperoleh data yang tepat dari variabel yang diteliti.Dalam penelitian ini digunakan validitas konstrukdengan menganalisa apa saja yang merupakan unsur-unsur suatu konstruk.Cara pengukurannya adalah dengan mencari korelasi antara masing-masing pertanyaan dengan skor total menggunakan teknik korelasi product momen sebagai berikut : 


$$
r=\frac{N\left(\sum_{i=1}^{N} X_{i} Y_{i}\right)-\left(\sum_{i=1}^{N} X_{i} \sum_{i=1}^{N} Y_{i}\right)}{\sqrt{\left[N \sum_{i=1}^{N} X_{i}^{2}-\left(\sum_{i=1}^{N} X_{i}\right)^{2}\right]\left[N \sum_{i=1}^{N} Y_{i}^{2}-\left(\sum_{i=1}^{N} Y_{i}\right)^{2}\right]}}
$$

dimana, $\mathrm{r}$ : Koefisien korelasi produk momen

$\mathrm{X}$ : Skor tiap pertanyaan/variabel

Y : Skor Total

$\mathrm{N}$ : Jumlah Responden

Setelah semua korelasi untuk setiap pertanyaan dengan skor total diperoleh, nilai-nilai tersebut dibandingkan dengan nilai tabel pearson product moment $\left(\mathrm{r}_{\alpha, \mathrm{df}}\right)$. Jika nilai koefisien korelasi produk momen dari suatu pertanyaan berada di atas nilai tabel kritik $\left(r>r_{\alpha, d f}\right)$, maka pertanyaan tersebut tersebut signifikan.

b) Uji Reliabilitas

Reliabilitas adalah tingkat keandalan kuisioner. Suatu alat ukur dikatakan reliable jika alat ukur tersebut memberikan hasil yang tetap atau sama selama variable yang diukur tidak berubah. Perlu diketahui bahwa alat ukur yang reliable mungkin tidak valid, sedangkan alat ukur yang valid pasti reliable. Reliabilitas Internal. Pada penelitian ini digunakan uji reliabilitas internal dengan menggunakan alpha, karena rumus yang lain hanya bisa digunakan apabila kategori jawaban yang hanya menggunakan variable diskrit yang diskoring menjadi 0-1.

Rumus Alpha :

Dimana, $\mathrm{r}_{11}$ : reliabilitas instrument

$$
\mathrm{r}_{11}=(\mathrm{k} /(\mathrm{k}-1))\left(1-\sum \text { ớ }_{\mathrm{b}}^{2} / \mathrm{o}_{\mathrm{t}}^{2}\right)
$$

$\sum$ ớ $_{\mathrm{b}}^{2}$ : jumlah varians butir

$\mathrm{K} \quad$ : banyaknya butir pertanyaan

ơ $_{\mathrm{t}}^{2} \quad$ : varians total

Jika suatu variable diatakan reliable bila variable tersebut mempunyai koefisien $\mathrm{r}$ alpha $\geq \mathrm{r}_{(\alpha, \mathrm{df})}$.

\section{HASIL PENELITIAN}

Berdasarkan hasil evaluasi faktor-faktor yang mempengaruhi konsumen dalam memilih jenis bus adalah untuk jenis bus Executive memiliki pelayanan awak bus yang lebih dibandingkan dengan jenis bus Suspensi Udara dan Scania. Bus Executive juga lebih tiba tepat waktu dibanding kedua jenis bus lainnya selain ituwaktu pemberangkatannya yang telah ditetapkan oleh pihak perusahaan yaitu pukul 21.30 Witasesuai dengan pilihan konsumen, dan jadwal keberangkatannya terpenuhi (on time) dibandingkan dengan Bus Executive dan Scania.Untuk jenis bus Scania, faktor yang mempengaruhi konsumen dalam memilih jenis bus ini adalah karena bus scania memiliki tingkat kenyamanan yang tinggi dibandingkan dengan kedua jenis bus lain, selain itu tingkat keamanan dan keselamatan barang bawaan penumpang juga lebih baik dibandingkan bus Executive dan bus Suspensi Udara

Adapun karakteristik penumpang yang menggunakanbus Executive adalah berjenis kelamin Perempuan, sebagian besar berumur antara 18-25 Tahun. Berdasarkan pekerjaan, sebagian besar penumpangbus Executive Belum/tidak bekerja yang di dalamnya adalah mahasiswa dan ibu rumah tangga.Penumpang bus 
Suspensi Udara didominasi berjenis Kelamin Laki-laki. Berdasarkan umur, yang paling banyak adalah berumur antara 17-25. Berdasarkan pekerjaan, Belum/tidak bekerja dan Wiraswasta mendominasi Bus ini, mengingat banyaknya yang menuntut ilmu di Kota Makassar merupakan salah satu yang mengakibatkan banyaknya mahasiswa yang melakukan perjalanan menggunakan Bus menuju Kota Makassar.Penumpang bus Scania yang paling banyak adalah perempuan, didominasi umur antara 25-33 Tahun, dimana usia ini memang lebih mementingkan sebuah kenyamanan dalam melakukan perjalanan. Berdasarkan pekerjaan,belum/tidak bekerja dan karyawan swasta yang paling banyak menggunakan bus Scania

\section{PEMBAHASAN}

Dalam melakukan penelitian tahapan yang dilakukan adalah:

a) Tahap persiapan. Yaitu dengan melakukan perhitungan jumlah sampel untuk melakukan mendapatkan informasi dari kuisioner. Perhitungan jumlah sampel dengan menggunakan rumus:

$$
n=\frac{N}{1+N(d)^{2}}
$$

Keterangan : $\quad \mathrm{n}:$ jumlah sampel

$\mathrm{N}$ : jumlah populasi

b) Identifikasi Variabel

d: tingkat signifikansi $(0,1)$

Identifikasi varibel Karakteristik Kinerja Moda Angkutan Umum Bus Bintang Prima adalah :

1) Karakteristik Faktor, meliputi: (a) Harga; (b) Kenyamanan; (c) Pelayanan Awak Bus; (d) Keamanan dan Keselamatan Penumpang; (e) Waktu Pemberangkatan; dan (f) Waktu Tempuh.

2) Karakteristik Penumpang, meliputi: (a) Umur; (b) Jenis Kelamin; dan (c) Pekerjaan.

Dalam analisa data ini, yang petama dilakukan adalahmemisahkan data yang akan digunakan untuk pengujian validitas dan reability dengan data yang akan digunakan untuk analisis faktor. Data yang digunakan untuk pengujian validitas dan reabilitas adalah sebanyak $25 \%$ dari semua total responden (Salim, 1993). Penjabarannya dapat dilihat sebagai berikut :

$=25 \%$ (responden executive + responden suspensi udara + responden scania $)$

$=25 \%(129+279+246)$

$=25 \%(654)$

$=163,5$

$=163,5 / 3$ jenis bus tersebut

$=54,5 \rightarrow 54$

Jadi, masing-masing jenis bus diambil sebanyak 54 sampel yang digunakan untuk pengujian validitas dan realibilitas. Sisa dari sampel itulah yang digunakan untuk analisis faktor.

c) Uji Validitas

Uji validitas dilakukan untuk mengukur apakah variabel-variabel yang dipergunakan untuk mengukur karakteristik faktor pada kuisioner benar-benar mengukur variabel yang seharusnya diukur. Kriteria valid adalah jika $r$ hitung $>$ $\mathrm{r}$ tabel atau nilai signifikan tidak lebih besar dari 0,005. Jika nilai koefisien korelasi produk momen dari suatu pertanyaan berada di atas nilai tabel kritik, 
maka pertanyaan tersebut signifikan. Dengan derajat bebas 160 dan nilai alpha 5 $\%$ maka didapat nilai $r$ tabel $=0,1546$.

Tabel 1. Uji Validitas Faktor-faktor yang Mempengaruhi Pemilihan Jenis Bus

\begin{tabular}{|c|c|c|c|c|}
\hline Atribut Layanan & $\begin{array}{c}\text { Nilai } \\
\text { R Hitung }\end{array}$ & $\begin{array}{c}\text { Nilai } \\
\text { R Tabel }\end{array}$ & $\begin{array}{l}\text { Nilai } \\
\text { Signifikan }\end{array}$ & Keputusan \\
\hline $\begin{array}{ll} & \text { Tarif } \\
\text { Harga Tiket } & \\
\end{array}$ & $-0,092$ & 0,1546 & 0,244 & tidak valid \\
\hline \begin{tabular}{l}
\multicolumn{1}{c}{ Kenyamanan } \\
1. Kursi Luas \\
2. Kursi Empuk \\
3. Kursi Nyaman \\
4. $\quad$ Fasilitas selimut \& bantal bersih \\
5. Suhu AC cukup \\
6. Lorong untuk berjalan cukup luas \\
7. Kondisi pintu memudahkan naik \& \\
turun dari bus \\
8. Toilet Bersih \\
9. Toilet menyediakan air yang cukup \\
10. Fasilitas hiburan yang membuat \\
nyaman \\
11. Terhindar dari polusi suara \\
12. Terhindar dari polusi udara
\end{tabular} & $\begin{array}{l}0,582 \\
0,739 \\
0,751 \\
0,668 \\
0,684 \\
0,308 \\
0,434 \\
0,559 \\
0,504 \\
0,359 \\
0,587 \\
0,665\end{array}$ & $\begin{array}{l}0,1546 \\
0,1546 \\
0,1546 \\
0,1546 \\
0,1546 \\
0,1546 \\
0,1546 \\
0,1546 \\
0,1546 \\
0,1546 \\
0,1546 \\
0,1546\end{array}$ & $\begin{array}{l}0,000 \\
0,000 \\
0,000 \\
0,000 \\
0,000 \\
0,000 \\
0,000 \\
0,000 \\
0,000 \\
0,000 \\
0,000 \\
0,000\end{array}$ & $\begin{array}{l}\text { valid } \\
\text { Valid } \\
\text { Valid } \\
\text { Valid } \\
\text { Valid } \\
\text { Valid } \\
\text { Valid } \\
\text { Valid } \\
\text { Valid } \\
\text { Valid } \\
\text { Valid } \\
\text { Valid }\end{array}$ \\
\hline $\begin{array}{l}\text { Pelayanan Awak Bus } \\
\text { 1. Kernek cekatan dalam melayani } \\
\text { penumpang } \\
\text { 2. Sopir tidak menggunakan } \\
\text { handphone } \\
\quad \text { saat mengemudi }\end{array}$ & $\begin{array}{l}0,608 \\
-0,012\end{array}$ & $\begin{array}{l}0,1546 \\
0,1546\end{array}$ & $\begin{array}{l}0,000 \\
0,879\end{array}$ & $\begin{array}{l}\text { Valid } \\
\text { tidak valid }\end{array}$ \\
\hline $\begin{array}{l}\text { Keamanan \& keselamatan Penumpang } \\
\text { 1. Perilaku sopir Tidak beresiko } \\
\text { terhadap } \\
\text { keselamatan penumpang } \\
\text { 2. Tempat menyimpan barang bawaan } \\
\text { aman } \\
\text { 3. Tidak mengalami kehilangan barang } \\
\text { 4. Tidak mengalami tertukar barang } \\
\text { 5. Tidak mengalami kecelakaan }\end{array}$ & $\begin{array}{l}0,656 \\
0,057 \\
0,298 \\
0,049\end{array}$ & $\begin{array}{l}0,1546 \\
0,1546 \\
0,1546 \\
0,1546 \\
0,1546\end{array}$ & $\begin{array}{l}0,754 \\
0,000 \\
0,472 \\
0,000 \\
0,536\end{array}$ & $\begin{array}{l}\text { tidak valid } \\
\text { Valid } \\
\text { tidak valid } \\
\text { Valid } \\
\text { tidak valid }\end{array}$ \\
\hline $\begin{array}{l}\text { Waktu Pemberangkatan } \\
\text { 1. Jadwal keberangkatan terpenuhi ( on } \\
\text { time ) } \\
\text { 2. Jam keberangkatn sesuai dengan } \\
\text { keinginan penumpang } \\
\text { Penumpang }\end{array}$ & $\begin{array}{l}0,243 \\
0,271\end{array}$ & $\begin{array}{l}0,1546 \\
0,1546\end{array}$ & $\begin{array}{l}0,002 \\
0,000\end{array}$ & $\begin{array}{l}\text { Valid } \\
\text { Valid }\end{array}$ \\
\hline $\begin{array}{l}\text { Waktu Tempuh } \\
\text { Tiba Tepat Waktu }\end{array}$ & 0,558 & 0,1546 & 0,000 & Valid \\
\hline
\end{tabular}

Sumber : Hasil Analisis

Pada tabel 1 dapat dilihat bahwa terdapat lima item variabel yang tidak valid, yakni harga tiket, pelayanan awak bus yaitu sopir tidak menggunakan handphone saat mengemudi, keamanan dan keselamatan penumpang yaitu perilaku sopir tidak beresiko terhadap keselamatan penumpang, tidak mengalami kehilangan barang, tidak mengalami kecelakaan. Sehingga dapat disimpulkan bahwa kelima item variabel tersebut tidak dapat digunakan untuk pengukuran selanjutnya atau dengan 
kata lain tidak termasuk sebagai faktor yang diperhitungkan dalam mempengaruhi pemilihan jenis bus.Variabel faktor yang tidak signifikan yaitu harga tiket, pelayanan awak bus yaitu sopir tidak menggunakan handphone saat mengemudi, keamanan dan keselamatan penumpang yaitu perilaku sopir tidak beresiko terhadap keselamatan penumpang, tidak mengalami kehilangan barang, tidak mengalami kecelakaan, dikeluarkan dan dilakukan pengujian validitas kembali. Hasilnya dapat dilihat pada tabel 2. setelah variabel yang tidak valid dikeluarkan, maka semua nilai $r$ hitung $>r$ tabel, sehingga dapat digunakan untuk analisis selanjutnya.

Tabel 2. Uji Validitas Faktor-faktor yang Mempengaruhi Pemilihan Jenis Bus

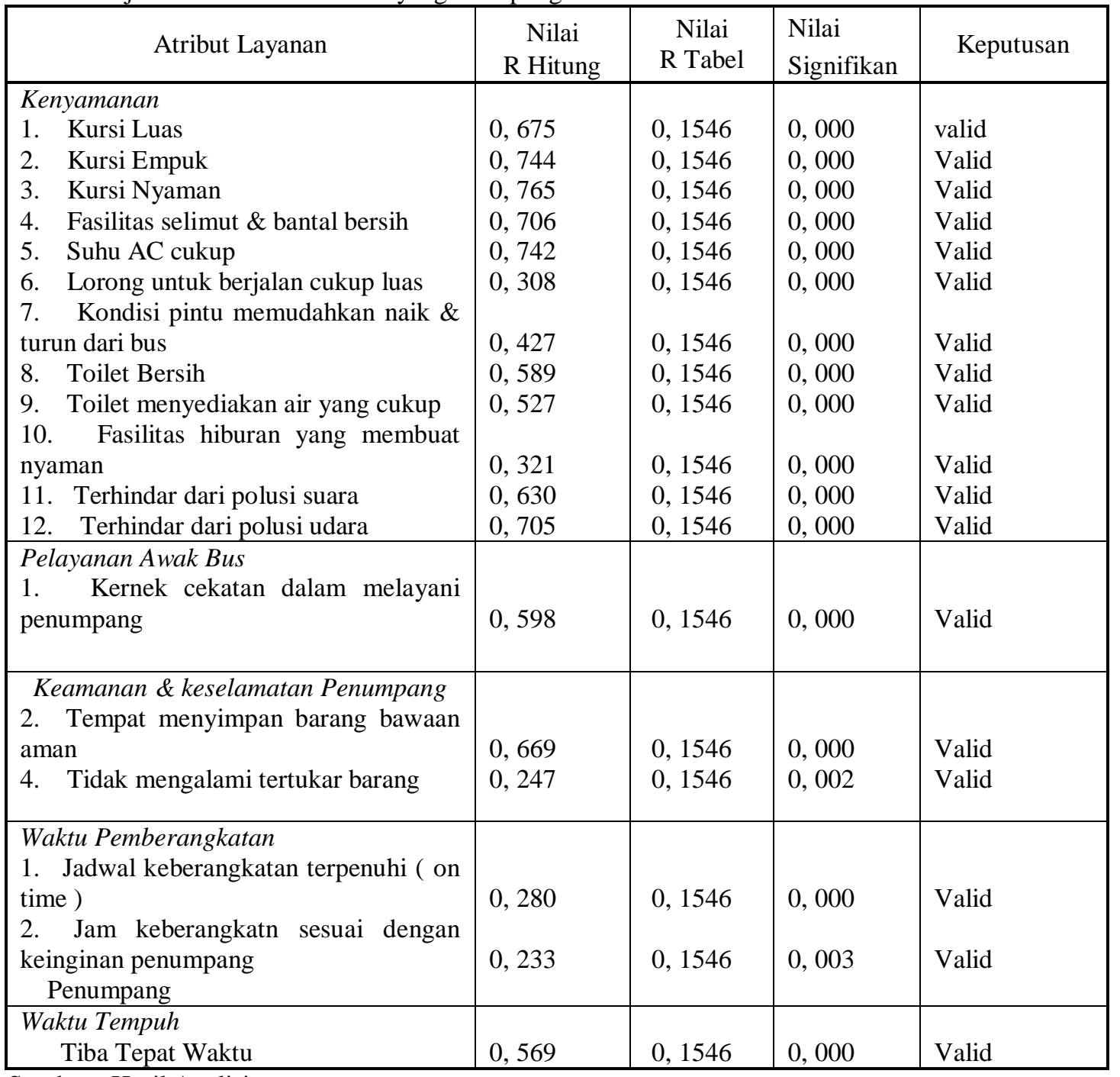

Sumber : Hasil Analisis

\section{d) Uji Reliabilitas}

Hasil Pengujian reliabilitas variabel faktor yang ditunjukkan pada tabel 3 dan diketahui bahwa semua nilai $\mathrm{r}$ alpha $>\mathrm{r}$ tabel $(0,1546)$ sehingga dapat disimpulkan variabel pengukur faktor-faktor reliabel.

Tabel 3. Uji Reliabilitas Faktor Pemilihan Jenis Bus

\begin{tabular}{|c|c|c|}
\hline Variabel Faktor & Nilai R Alpha & Nilai R tabel \\
\hline
\end{tabular}




\begin{tabular}{|c|c|c|}
\hline - Kursi Luas & 0.848 & 0.1546 \\
\hline - Kursi Empuk & 0.844 & 0.1546 \\
\hline - Kursi Nyaman & 0.844 & 0.1546 \\
\hline - $\quad$ Selimut dan bantal bersih & 0.846 & 0.1546 \\
\hline - Suhu AC cukup & 0.846 & 0.1546 \\
\hline - $\quad$ Lorong Bus Cukup Luas & 0.867 & 0.1546 \\
\hline $\begin{array}{l}\text { - Kondisi pintu tidak menyulitkan naik/turun } \\
\text { Bus }\end{array}$ & 0.860 & 0.1546 \\
\hline - Toilet Bersih & 0.853 & 0.1546 \\
\hline - $\quad$ Toilet menyediakan air yang cukup & 0.855 & 0.1546 \\
\hline - Fasilitas hiburan membuat nyaman & 0.865 & 0.1546 \\
\hline - Terhindar dari polusi suara & 0.851 & 0.1546 \\
\hline - $\quad$ Terhindar dari polusi udara & 0.847 & 0.1546 \\
\hline $\begin{array}{l}\text { Kernek cekatan dalam melayani } \\
\text { penumpang }\end{array}$ & 0.852 & 0.1546 \\
\hline - Tempat menyimpan barang bawaan aman & 0.849 & 0.1546 \\
\hline - Tidak mengalami tertukar barang & 0.864 & 0.1546 \\
\hline - Jadwal berangkat on time & 0.867 & 0.1546 \\
\hline - Jam keberangkatan sesuai & 0.866 & 0.1546 \\
\hline - Tiba tepat waktu & 0.854 & 0.1546 \\
\hline
\end{tabular}

\section{KESIMPULAN DAN SARAN}

Berdasarkan hasil evaluasi faktor-faktor yang mempengaruhi konsumen dalam memilih jenis bus yang akan digunakan dan karakteristik konsumen berdasarkan masing-masing jenis bus yang dipilih, dapat disimpulkan :

1) Faktor yang Mempengaruhi Konsumen dalam Memilih Jenis Bus

Faktor yang mempengaruhi konsumen dalam memilih Jenis Bus Executive karena Bus Executive memiliki pelayanan awak bus yang lebih dibandingkan dengan Jenis Bus Suspensi Udara dan Scania, selain itu Bus Executive juga lebih tiba tepat waktu dibanding kedua Jenis Bus lainnya. Faktor yang mempengaruhi konsumen dalam memilih Jenis Bus Suspensi Udara karena waktu pemberangkatannya yang telah ditetapkan oleh pihak perusahaan yaitu pukul 21.30 Wita sesuai dengan pilihan konsumen, dan jadwal keberangkatannya terpenuhi (on time) dibandingkan dengan Bus Executive dan Scania. Faktor yang mempengaruhi konsumen dalam memilih Jenis Bus Scania adalah karena Bus ini memiliki tingkat kenyamanan yang tinggi dibandingkan dengan kedua jenis Bus lain, selain itu tingkat keamanan dan keselamatan barang bawaan penumpang juga lebih baik dibandingkan Bus Executive dan Bus Suspensi Udara.

2) Karakteristik Penumpang

Penumpang yang banyak menggunakan Bus Executive adalah berjenis kelamin Perempuan, sebagian besar berumur antara 18-25 Tahun. Berdasarkan pekerjaan, sebagian besar penumpang Bus Executive Belum/tidak bekerja yang di dalamnya adalah mahasiswa dan ibu rumah tangga. Penumpang Bus Suspensi Udara didominasi berjenis Kelamin Laki-laki. Berdasarkan umur, yang paling banyak adalah berumur antara 17-25. Berdasarkan pekerjaan, Belum/tidak bekerja dan 
Wiraswasta mendominasi Bus ini, mengingat banyaknya yang menuntut ilmu di Kota Makassar merupakan salah satu yang mengakibatkan banyaknya mahasiswa yang melakukan perjalanan menggunakan Bus menuju Kota Makassar. Penumpang Bus Scania yang paling banyak adalah Perempuan, didominasi umur antara 25-33 Tahun, dimana usia ini memang lebih mementingkan sebuah kenyamanan dalam melakukan perjalanan. Berdasarkan pekerjaan, belum/tidak bekerja dan Karyawan Swasta yang paling banyak menggunakan Bus Scania

\section{DAFTAR PUSTAKA}

Asikin,Muslich Zainal. 2001. "Sistem Manajemen Transportasi Kota”. Jakarta.

Djakfar, Ludfy. 2010. "Studi Karakteristik dan Model Pemilihan Moda", Universitas Brawijaya. Malang.

Fidel Miro, 2011. "Pengantar Sistem Transportasi”, Erlangga, Jakarta.

Hasam, M Iqbal. 2002. "Pokok-pokok Materi Metodologi Penelitian dan Aplikasi", Ghalia, Indonesia.

Judhi Pratikno, Herry.2006. "Analisis Intensitas Penggunaan Angkutan Penumpang Umum”, Universitas Diponegoro. Semarang.

Papacostas, C.S. 1987. "Fundamentals of Transportation Engineering". New Jersey.

Santoso G. 2005. "Metodologi Penelitian (Kuantitatif dan Kualitatif”). Prestasi Pustaka Publisher. Jakarta.

Sugiyono, 2009, "Metode Penelitian Administrasi", Alfabeta, Bandung.

Suwardjoko. 2002. "Pengelolaan Lalulinas dan Angkutan Jalan", ITB. Bandung.

Wicaksono, Sabdo. 2010. "Analisa Faktor-faktor yang Mempengaruhi Pemilihan Moda Transportasi”, Jurnal Teknik Sipil, Universitas Gunadarma, Jakarta.

Yamin, Jinca. 2007. "Dasar-dasar Transportasi”. Universitas Hasanuddin Makassar. 